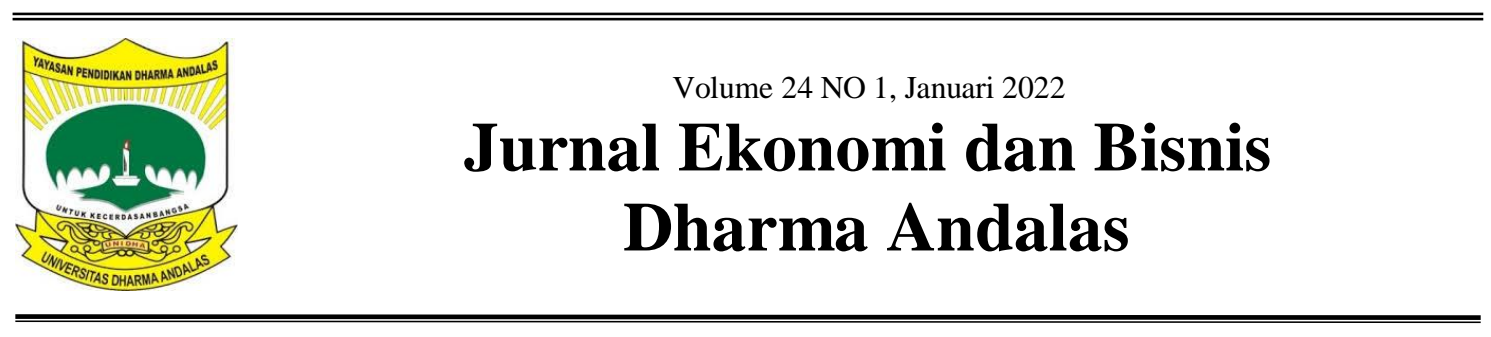

\title{
Identifikasi Potensi Wisata Syariah dan Strategi Pengembangannya ditengah Pandemi Covid-19 di Kabupaten Pesisir Selatan
}

\author{
Ezizwita $^{1}$, Firsta ${ }^{2}$, Tri Sukma ${ }^{3}$ \\ Fakultas Ekonomi dan Bisnis Universitas Dharma Andalas ${ }^{1,2,3}$ \\ email:ezizwitawita@gmail.com ${ }^{1}$ \\ firsta.ws@gmail.com² \\ sukmatri165@gmail.com ${ }^{3}$
}

\begin{abstract}
This study aims to identify tourism potential that carries the concept of sharia to be applied in Pesisir Selatan Regency and the strategy for developing sharia tourism in accordance with the current pandemic situation. The research method used is descriptive qualitative. The results of the SWOT analysis show that the strategy that can be used to develop sharia tourism in Pesisir Selatan Regency is an aggressive strategy. Analysis of internal and external factors shows the potential for sharia tourism in Pesisir Selatan Regency is in grow and build position. The alternative strategy is market penetration, market development, and tourism product development. The development of sharia tourism in a pandemic condition must follow several guidelines, such as implementing strict health protocols in tourist areas, frequently clean the service area with disinfectant, prioritize take away service and delivery orders, utilizing non-cash transactions to minimize the risk of virus transmission, process and package products hygienically and provide of foods that can increase the body's immunity.Tourism industry stakeholders need to create various incentives to encourage tourism demand, such as offering discount flights or hotels and accommodation at tourist attractions.
\end{abstract}

Keywords: sharia tourism, SWOT analysis, strategy, pandemic.

\begin{abstract}
ABSTRAK
Penelitian ini bertujuan untuk mengidentifikasi potensi wisata yang mengusung konsep syariah untuk diterapkan di Kabupaten Pesisir Selatan dan strategi pengembangan wisata syariah tersebut sesuai dengan situasi pandemi saat ini. Metode penelitian yang digunakan adalah kualitatif deskriptif. Hasil analisa SWOT menunjukkan strategi yang dapat digunakan untuk mengembangkan wisata syariah di Kabupaten Pesisir Selatan adalah strategi agresif yaitu memanfaatkan seluruh kekuatan untuk merebut dan memanfaatkan peluang sebesar-besarnya. Analisa faktor internal dan eksternal, potensi wisata syariah di Kabupaten Pesisir Selatan berada dalam posisi tumbuh dan membangun (grow and built). Alternatif strategi yang tepat adalah melakukan penetrasi pasar, pengembangan pasar, dan pengembangan produk wisata. Pengembangan wisata syariah di tengah pandemi harus mengikuti beberapa panduan, seperti menerapkan protokol kesehatan ketat di area wisata dan tempat berkumpul. Sering membersihkan area servis dengan desinfektan untuk memenangkan kepercayaan wisatawan, mengutamakan take away service dan delivery order. Memanfaatkan transaksi non tunai untuk memperkecil resiko penularan virus. Pengemasan produk secara higienis. Beralih ke menu makanan yang dapat meningkatkan imunitas tubuh. Para pemangku kepentingan industri pariwisata perlu membuat
\end{abstract}


berbagai insentif untuk mendorong permintaan pariwisata, seperti memberi penawaran diskon pesawat atau hotel dan akomodasi di tempat wisata.

Kata kunci : wisata syariah, analisis SWOT, strategi, pandemi.

\section{PENDAHULUAN}

Pariwisata merupakan sektor industri jasa yang sangat potensial dikembangkan di Indonesia. Jumlah kunjungan wisatawan mancanegara dan wisatawan nusantara terus menunjukkan peningkatan dari tahun ke tahun, sebelum terjadinya pandemi Covid-19. Pada tahun 2018 dengan pertumbuhan 22\%, Indonesia berada di posisi ke-9 sebagai negara dengan pertumbuhan wisatawan mancanegara tercepat di dunia, nomor 3 di Asia dan nomor 1 di Asia Tenggara menurut World Travel \& Tourism Council (WTTC). Indeks daya saing pariwisata Indonesia pun ikut naik dari peringkat 70 dunia di tahun 2013, meroket ke posisi 42 besar di 2017 (https://news.okezone.com/read/2018/ 12/21/1/1994416/pariwisata-indonesiajadi-sumber-devisa-kemenpar-mantaptatap-2019).

Sebagai salah satu sektor andalan untuk menambah pemasukan finansial bagi setiap negara di dunia, persaingan di bidang pariwisata ini pun semakin ketat. Hal ini disikapi serius oleh Pemerintah Indonesia dengan berbagai program strategis. Setiap daerah pun terus berlomba membangun pariwisata di daerah mereka masing-masing yang terlihat dari tingginya permintaan atau usulan Dana Alokasi Khusus (DAK) Pariwisata tahun 2019. Selain itu, dalam memajukan sektor pariwisata, daerah juga gencar meningkatkan kualitas Sumber Daya Pariwisata (SDM) dan mensinergikan program daerah dengan pemerintah pusat (Kemenpar).

Provinsi Sumatera Barat sendiri merupakan salah satu destinasi wisata bagi wisatawan nasional dan dunia. Menurut Dinas Pariwisata Sumbar, sepanjang tahun 2016 kunjungan wisatawan domestik yang dihitung kasar sekitar 7,3 juta orang. (https://www.liputan6.com/bisnis/read/3 209609/sumatera-barat-dikunjungi-78juta-wisatawan-domestik-tahun-ini).

Kunjungan ini juga mengalami peningkatan dari tahun 2017 sampai dengan tahun 2019. Rata-rata peningkatan tahunan sebesar 2,45\% (https://sumbartravel.com/wpcontent/uploads/dataupload/statistik\%20 pariwisata\%20sumbar-2020.pdf).

Kemudian berdasarkan data dari BPS Sumbar dilangsir dari laman https://sumatra.bisnis.com/read/2019020 4/534/885208/jumlah-wisman-ke-

sumbar-2018-turun-441, kunjungan wisatawan mancanegara ke Sumatra Barat sepanjang tahun 2018 yang sempat turun 4,41\% dibandingkan dengan 2017 yang 56.876 orang akibat ditutupnya penerbangan langsung maskapai Air Asia rute Padang - Singapura, kembali mengalami peningkatan sebesar $12,44 \%$ menjadi 61.131 orang pada tahun 2019 .

Dinas Pariwisata Provinsi Sumatera Barat menyebutkan, tingginya minat wisatawan mengunjungi Sumatera Barat didorong oleh perbaikan infrastruktur, berbagai promosi wisata, dan kebijakan pemda yang menjadikan pariwisata sebagai prioritas utama pembangunan Sumatera Barat. Ditambah lagi, ditetapkannya Sumatera Barat sebagai daerah tujuan pariwisata halal dunia dalam ajang World Halal Tourism di Abu Dhabi tahun 2016, ikut menaikkan pamor pariwisata Sumatera Barat. Beberapa destinasi yang menjadi unggulan Provinsi Sumatera Barat adalah sejumlah objek wisata di Kota Padang, Bukittinggi, Mandeh dan Pantai Carocok di Pesisir Selatan, Istana Pagaruyung di Tanah Datar, Sawalunto, dan Solok Selatan.

(https://www.liputan6.com/bisnis/read/3 
209609/sumatera-barat-dikunjungi-78juta-wisatawan-domestik-tahun-ini).

Gubernur Sumatera Barat telah menetapkan 10 Daerah tingkat II sebagai daerah destinasi wisata. yaitu Kota Padang, Kota Bukittingi, Kabupaten 50 Kota, Sawahlunto, Kabupaten Pesisir Selatan, Kabupaten Solok, Kabupaten Tanah Datar, Kabupaten Agam, Kabupaten Padang Pariaman dan Kabupaten Mentawai. (Haluan.wordpress.com/2007).

Kabupaten Pesisir Selatan sendiri pada tahun 2017 dan 2018 mendapat kunjungan paling banyak ketiga dibandingkan dengan kota/kabupaten lain di Sumatra Barat dan tahun 2019 sudah berada di urutan kedua setelah Kepulauan Mentawai, menurut BPS Provinsi Sumatra Barat. (https://sumbartravel.com/wpcontent/uploads/dataupload/statistik\%20 pariwisata\%20sumbar-2020.pdf).

Kenyataan tersebut tentunya menjadi suatu motivasi dan tantangan bagi Kabupaten Pesisir Selatan untuk terus meningkatkan promosi dan pelayanannya terhadap para wisatawan yang berkunjung. Pemkab Pesisir Selatan juga terus berupaya melakukan perbaikan pelayanan bagi pengunjung agar mereka merasa aman dan nyaman saat berada di lokasi wisata.

Ditetapkannya Sumatera Barat sebagai daerah tujuan pariwisata halal dunia, selayaknya dijadikan momentum oleh Pemerintah Daerah Kabupaten Pesisir Selatan untuk menerapkan pariwisata berbasis syariah di wilayahnya. Wisata syariah ini mempertimbangkan nilai-nilai syariah Islam dalam pelayanannya seperti akomodasi wisata yang sesuai dengan tuntunan ajaran Islam, makanan yang tersedia harus halal dan tidak menyediakan menu yang diharamkan, dan seterusnya. Konsep wisata syariah yang menerapkan nilai-nilai keislaman ke dalam seluruh aspek kegiatan wisata, sangat sesuai untuk Provinsi Sumatra Barat yang penduduknya mayoritas beragama Islam, termasuk Kabupaten Pesisir Selatan.

Tujuan penelitian ini adalah mengidentifikasi potensi wisata yang mengusung konsep syariah untuk diterapkan di Kabupaten Pesisir Selatan dan strategi pengembangannya sesuai dengan situasi pandemi saat ini. Melalui analisis SWOT akan dikupas peluang dan tantangan yang dihadapi oleh dunia wisata khususnya wisata syariah sehingga diperoleh suatu strategi yang secara praktis bisa diterapkan untuk mengembangkan wisata syariah. Tujuan umumnya adalah untuk memperkaya wawasan semua pihak yang berkepentingan dalam identifikasi potensi dan pengembangan wisata, khususnya wisata syariah.

\section{Pengertian Pariwisata}

Dalam pengertian umum, pariwisata adalah serangkaian kegiatan perjalanan yang dilakukan oleh perorangan atau kelompok dari tempat tinggal asalnya ke tempat lain dengan tujuan melakukan refreshing, berlibur dan bersenang-senang menikmati suasana tempat tujuan tersebut.

Organisasi pariwisata dunia UNWTO (United Nation World Tourism Organization) mendefinisikan pariwisata sebagai kegiatan dari seseorang yang bepergian atau tinggal di suatu tempat di luar lingkungannya biasanya dalam waktu tidak lebih dari satu tahun berurutan untuk berwisata, bisnis, atau tujuan lain dengan tidak untuk bekerja di tempat yang dikunjunginya tersebut. (Suryadana dkk 2015)

Menurut undang-undang No.9 tahun 1990 pasal 1 tentang kepariwisataan menyebutkan bahwa pariwisata adalah segala sesuatu yang berhubungan dengan wisata, termasuk pengusahaan objek dan daya tarik wisata 
serta usaha-usaha yang terkait dibidang tersebut. Kepariwisataan menurut Tap MPRS tahun 1960 adalah suatu cara untuk memenuhi kebutuhan manusia dalam memberikan hiburan rohani dan jasmani, setelah beberapa waktu bekerja serta mempunyai modal untuk melihatlihat daerah lain (wisatawan nusantara) atau negara-negara lain (wisatawan mancanegara). (Gunardi, 2010).

\section{Konsep Pariwisata Syariah}

Dari sisi industri, wisata syariah merupakan suatu produk pelengkap dan tidak menghilangkan jenis pariwisata konvensional. Sebagai cara baru untuk mengembangkan pariwisata Indonesia yang menjunjung tinggi budaya dan nilainilai Islami tanpa menghilangkan keunikan dan orisinalitas daerah. (Kemenpar. Kemenparekraf Promosikan Indonesia Sebagai Destinasi Pariwisata Syariah Dunia. http://www.kemenpar.go.id).

Konsep pariwisata syariah adalah suatu proses implementasi nilai Islam ke dalam aktivitas wisata. Konsep dasar pariwisata syariah adalah pemaknaan terhadap segala aktivitas pariwisata yang meliputi sarana penginapan, transportasi, makanan dan minuman, sistem keuangan, hingga fasilitas dan penyedia jasa yang baik serta bijaksana (Priyadi, 2016).

World Tourism Organization (WTO) mengkampanyekan bahwa konsumen wisata syariah tidak hanya khusus muslim, akan tetapi seluruh wisatawan non muslim sekali pun yang ingin menikmati kearifan lokal (Jaelani, 2017 dalam Noviantoro, 2020)

Dalam Sucipto dan Andayani (2014), Kementerian PariwisataEkonomi Kreatif dan Dewan Syariah Nasional Majelis Ulama Indonesia menetapkan standar kriteria pariwisata syariah, yaitu bertujuan untuk kesejahteraan sosial, bertujuan pada penyegaran, pendidikan, dan kedamaian, menjauhkan dari khurofat dan kemusyrikan, menjauhkan dari perbuatan buruk, seperti zina, pornoaksi, pornografi, minuman keras, narkoba dan judi, memperhatikan perilaku, etika dan nilai luhur kemanusiaan, seperti tidak bersikap acuh dan amoral, memperhatikan keamanan, terpercaya, dan ketentraman, berkarakter inklusif serta universal, memperhatikan konservasi lingkungan, dan meluhurkan nilai-nilai sosial budaya dan kearifan lokal.

Ada beberapa panduan umum dalam pariwisata syariah menurut Sucipto dan Andayani (2014), yaitu:

a. Objek Wisata

Kriteria objek wisata syariah adalah ada objek wisata meliputi wisata alam, wisata budaya, dan wisata buatan, tersedia fasilitas ibadah yang layak dan suci, tersedia makanan dan minuman halal, Pertunjukan seni dan budaya serta atraksi yang tidak bertentangan dengan kriteria umum pariwisata syariah, dan terjaga kebersihan sanitasi dan lingkungan.

b. Akomodasi

Kriteria akomodasi syariah adalah tersedia fasilitas yang layak untuk bersuci, tersedia fasilitas yang memudahkan untuk beribadah, tersedia makanan dan minuman yang halal, fasilitas dan suasana yang aman, nyaman, dan kondusif untuk keluarga dan bisnis, dan terjaga kebersihan sanitasi dan lingkungan.

c. Usaha penyedia makanan dan minuman

Kriterianya adalah harus terjamin kehalalannya, mulai dari bahan baku hingga proses pengelolahannya. Adanya sertifikat halal dari MUI, minimal jaminan halal dari tokoh muslim atau pihak terpercaya, dengan memenuhi ketentuan yang ada dan terjaga lingkungan yang sehat dan bersih.

d. Biro Perjalanan Wisata 
Kriteria biro perjalanan wisata syariah adalah menyelenggarakan paket perjalanan atau wisata yang sesuai dengan kriteria umum pariwisata syariah, memiliki daftar akomodasi yang sesuai dengan panduan umum akomodasi pariwisata syariah, memiliki daftar usaha penyedia makanan dan minuman yang sesuai dengan panduan umum usaha penyedia makanan dan minuman pariwisata syariah.

\section{e. Pramuwisata Syariah}

Kriteria pramuwisata syariah adalah memahami dan mampu melaksanakan nilai-nilai syariah dalam menjalankan tugas, berakhlak baik, komunikatif, ramah, jujur, dan bertanggung jawab, berpenampilan sopan dan menarik sesuai dengan nilai dan etika Islam, dan memiliki kompetensi kerja sesuai standar profesi yang berlaku.

\section{f. Aksebilitas}

Kriteria aksebilitas adalah kemudahan akses informasi wisata syariah, objek wisata mudah dijangkau, akses transportasi memadai, dan biaya transportasi sesuai standar yang berlaku.

\section{Pengembangan Wisata Syariah}

Pengembangan

pariwisata

bertujuan untuk menarik kedatangan wisatawan sebanyak-banyaknya, menghabiskan waktu lebih lama dan mengeluarkan uang lebih banyak di lokasi tujuan wisata. Dengan demikian diharapkan wisatawan mendapatkan pengalaman yang lebih menyenangkan, perekonomian pelaku usaha wisata dan masyarakat lebih meningkat, sekaligus menambah pendapatan asli daerah dan devisa negara.

Pengembangan pariwisata dapat dilakukan dengan menggunakan Analisis SWOT, yang banyak digunakan dalam segi pengembangan bisnis, termasuk pariwisata.

\section{Pengertian Strategi}

Rangkuti (2014) mengatakan
bahwa strategi adalah alat untuk
mencapai tujuan. Daft (2010)
mendefinisikan strategi secara eksplisit, yaitu rencana tindakan yang menerangkan tentang alokasi sumber daya serta berbagai aktivitas untuk menghadapi lingkungan, memperoleh keunggulan bersaing, dan mencapai tujuan perusahaan. Pearce dan Robinson, seperti yang dikutip dari Sancoko (2015), mendefinisikan strategi sebagai rencana dalam skala besar dan berorientasi pada masa depan untuk berinteraksi dengan lingkungan yang kompetitif agar dapat mencapai tujuan objektif perusahaan.

\section{Analisa SWOT}

Analisa SWOT menurut Rangkuti (2014) adalah identifikasi berbagai faktor secara sistematis untuk merumuskan strategi perusahaan. Analisis ini didasarkan pada logika yang dapat memaksimalkan kekuatan (strength) dan peluang (opportunities), namun secara bersamaan dapat meminimalkan kelemahan (weakness) dan ancaman (threats). Proses pengambilan keputusan strategis selalu berkaitan dengan pengembangan misi, tujuan, strategis dan kebijakan perusahaan. Dengan demikian perencanaan strategis harus menganalisis faktor-faktor strategis perusahaan (kelemahan, kekuatan, peluang dan ancaman) dan kondisi yang ada pada saat ini.

\section{METODE PENELITIAN}

Penelitian ini menggunakan metode deskriptif dengan pendekatan kualitatif, yaitu penelitian yang dilakukan dengan memberikan gambaran yang lebih detail mengenai suatu gejala atau fenomena dengan melihat objeknya berupa kondisi saat ini yang sedang berlangsung. 
Data penelitian dianalisis dengan menggunakan statistik deskriptif, dengan interpretasi nilai rata-rata skor, memetakan dan menganalisis matriks SWOT. Tahapan kegiatan yang dilakukan dalam analisis SWOT adalah mengidentifikasi faktor-faktor internal dan eksternal, menyusun kuesioner, dan kemudian menganalisis data.

Populasi dalam penelitian ini adalah semua destinasi wisata yang ada di Kabupaten Pesisir Selatan. Untuk sampel diambil sebanyak 7 (tujuh) buah destinasi, yaitu Kawasan Wisata Mandeh, Pantai Carocok, Bukit Langkisau, Pantai Salido, Simpang Tigo Buayo Putiah,
Pantai Batu Kalang dan Jembatan Akar. Dari setiap tempat wisata dipilih 15 orang secara acak untuk dijadikan responden.

\section{HASIL DAN PEMBAHASAN \\ Faktor Internal dan Eksternal Potensi Wisata di Kabupaten Pesisir Selatan}

Dari hasil pengolahan data diperoleh faktor-faktor strategis internal dan eksternal yang ditemukan dalam mengidentifikasi potensi wisata syariah di Kabupaten Pesisir Selatan. Hasil analisis tersebut digunakan untuk menentukan faktor yang termasuk dalam kekuatan dan kelemahan serta peluang dan ancaman.

Analisis Internal Factor Analysis Summary (IFAS)

Hasil penghitungan faktor internal potensi wisata syariah di Pesisir Selatan:

Tabel 1. Matrik IFAS Potensi Wisata Syariah

\begin{tabular}{|c|c|c|c|c|}
\hline No & Kekuatan (Strength) & Bobot & Rating & Nilai \\
\hline 1 & $\begin{array}{l}\text { Memiliki daya tarik wisata alam } \\
\text { yang menarik }\end{array}$ & 0.060 & 3.590 & 0.215 \\
\hline 2 & $\begin{array}{l}\text { Memiliki daya tarik wisata } \\
\text { budaya yang menarik }\end{array}$ & 0.060 & 2.962 & 0.178 \\
\hline 3 & $\begin{array}{l}\text { Makanan dan minuman halal di } \\
\text { destinasi wisata mudah } \\
\text { diperoleh }\end{array}$ & 0.070 & 3.552 & 0.249 \\
\hline 4 & $\begin{array}{l}\text { Pertunjukan seni dan budaya } \\
\text { serta atraksi tidak bertentangan } \\
\text { dengan syariah }\end{array}$ & 0.060 & 3.514 & 0.211 \\
\hline 5 & $\begin{array}{l}\text { Hotel atau penginapan lainnya } \\
\text { menyediakan fasilitas yang } \\
\text { layak untuk bersuci }\end{array}$ & 0.070 & 3.405 & 0.238 \\
\hline 6 & $\begin{array}{l}\text { Hotel atau penginapan lainnya } \\
\text { menyediakan fasilitas yang } \\
\text { memudahkan untuk beribadah }\end{array}$ & 0.070 & 3.238 & 0.227 \\
\hline 7 & $\begin{array}{l}\text { Hotel atau penginapan lainnya } \\
\text { menyediakan makanan dan } \\
\text { minuman yang halal }\end{array}$ & 0.070 & 3.548 & 0.248 \\
\hline 8 & $\begin{array}{l}\text { Suasana hotel atau penginapan } \\
\text { lainnya sudah aman, nyaman } \\
\text { dan kondusif untuk keluarga }\end{array}$ & 0.045 & 3.429 & 0.154 \\
\hline 9 & $\begin{array}{l}\text { Suasana hotel atau penginapan } \\
\text { lainnya sudah aman, nyaman } \\
\text { dan kondusif untuk keperluan } \\
\text { bisnis }\end{array}$ & 0.040 & 3.238 & 0.130 \\
\hline
\end{tabular}


Kebersihan sanitasi dan

10 lingkungan di hotel atau penginapan lainnya terjaga

dengan baik

Restoran atau tempat makan

lainnya di tempat wisata

11 menyediakan makanan dan

minuman yang terjamin

kehalalannya

Adanya jaminan halal dari

12 majelis Ulama Indonesia (MUI)

pada makanan dan minuman

$0.060 \quad 2.676 \quad 0.161$

yang dijual di tempat wisata

$\begin{array}{lll}0.070 & 3.514 & 0.246\end{array}$

Kebersihan sanitasi dan lingkungan pada penyedia

13 makanan dan minuman di tempat wisata sudah terjaga dengan baik

\begin{tabular}{ccccc}
\hline \multicolumn{1}{c}{ Sub Total } & 0.805 & 3.297 & 2.659 \\
\hline No & $\begin{array}{c}\text { Kelemahan (Weakness) } \\
\text { Pesisir Selatan belum memiliki } \\
\text { daya tarik wisata buatan yang } \\
\text { menarik }\end{array}$ & Bobot & Rating & Nilai \\
$\begin{array}{l}\text { Tempat wisata belum } \\
\text { menyediakan tempat ibadah } \\
\text { layak dengan sarana bersuci } \\
\text { yang memadai } \\
\text { Tempat wisata belum menjaga } \\
\text { kebersihan sanitasi dan } \\
\text { lingkungan }\end{array}$ & 0.060 & 2.029 & 0.122 \\
\hline Sub Total & 0.195 & 2.371 & 0.166 \\
\hline TOTAL & 1.000 & 2.263 & 0.443 \\
\hline
\end{tabular}

Kekuatan utama dengan nilai tertinggi adalah "Makanan dan minuman halal di destinasi wisata di Pesisir Selatan mudah diperoleh" $(0,249)$. Hal tersebut bisa dipahami, mengingat masyarakat Pesisir Selatan dan Sumatra Barat pada umumnya memang mayoritas beragama Islam. Sedangkan kelemahan utama dengan nilai tertinggi $(0,166)$ adalah "Tempat wisata di Pesisir Selatan sudah menyediakan tempat ibadah layak dan dilengkapi dengan sarana bersuci yang memadai". Hal ini menunjukkan bahwa bagi sebagian besar responden, tempattampat wisata di Pesisir Selatan belum menyediakan tempat ibadah yang layak, yang dilengkapi pula dengan sarana bersuci yang memadai.

Matrik IFAS menunjukkan skor nilai potensi wisata syariah sebesar 3,102 berada di atas nilai rata-ratanya yang sebesar 2,780 dari keseluruhan faktor 
internalnya. Sedangkan hasil nilai kekuatan (strenghts) sebesar 2,659 menunjukkan angka yang lebih tinggi dibandingkan dengan kelemahan (weaknesses) yang hanya sebesar 0,443 .
Kedua nilai terpaut jauh menunjukkan bahwa wisata syariah memiliki potensi yang sangat besar untuk dikembangkan di Kabupaten Pesisir Selatan.

\section{Analisis External Factor Analysis Summary (EFAS)}

Hasil penghitungan faktor eksternal potensi wisata syariah di Pesisir Selatan:

\section{Tabel 2.}

Matrik EFAS Potensi Wisata Syariah

\begin{tabular}{|c|c|c|c|c|}
\hline No & Peluang (Opportunities) & Bobot & Rating & Nilai \\
\hline 1 & $\begin{array}{l}\text { Biro perjalanan wisata menyediakan } \\
\text { paket wisata yang sesuai dengan } \\
\text { kriteria umum pariwisata syariah }\end{array}$ & 0.125 & 2.727 & 0.341 \\
\hline 2 & $\begin{array}{l}\text { Pramuwisata memahami dan mampu } \\
\text { melaksanakan nilai-nilai syariah } \\
\text { dalam bertugas }\end{array}$ & 0.075 & 3.273 & 0.245 \\
\hline 3 & $\begin{array}{l}\text { Pramuwisata memiliki akhlak yang } \\
\text { baik, komunikatif, ramah, jujur dan } \\
\text { bertanggungjawab }\end{array}$ & 0.075 & 2.864 & 0.215 \\
\hline 4 & Objek wisata mudah dijangkau & 0.090 & 3.200 & 0.288 \\
\hline 5 & $\begin{array}{l}\text { Akses transportasi dari dan menuju } \\
\text { tempat wisata sudah memadai }\end{array}$ & 0.100 & 3.600 & 0.360 \\
\hline & Sub Total & 0.465 & 3.133 & 1.449 \\
\hline No & Ancaman (Threats) & Bobot & Rating & Nilai \\
\hline 1 & $\begin{array}{l}\text { Biro perjalanan wisata belum } \\
\text { memiliki daftar akomodasi yang } \\
\text { sesuai dengan panduan umum } \\
\text { pariwisata syariah }\end{array}$ & 0.125 & 2.364 & 0.295 \\
\hline 2 & $\begin{array}{l}\text { Biro perjalanan wisata belum } \\
\text { memiliki daftar usaha penyedia } \\
\text { makanan dan minuman yang sesuai } \\
\text { dengan panduan umum pariwisata } \\
\text { syariah }\end{array}$ & 0.075 & 2.364 & 0.177 \\
\hline 3 & $\begin{array}{l}\text { Pramuwisata belum berpenampilan } \\
\text { sopan dan menarik sesuai dengan } \\
\text { nilai etika Islam }\end{array}$ & 0.075 & 2.409 & 0.181 \\
\hline 4 & $\begin{array}{l}\text { Pramuwisata belum memiliki } \\
\text { kompetensi kerja sesuai dengan } \\
\text { standar profesi yang berlaku }\end{array}$ & 0.075 & 2.227 & 0.167 \\
\hline 5 & $\begin{array}{l}\text { Informasi mengenai tempat wisata } \\
\text { belum mudah diperoleh }\end{array}$ & 0.085 & 2.448 & 0.208 \\
\hline 6 & $\begin{array}{l}\text { Biaya transportasi dari dan menuju } \\
\text { tempat wisata belum sesuai standar } \\
\text { yang berlaku }\end{array}$ & 0.100 & 2.362 & 0.236 \\
\hline
\end{tabular}




\begin{tabular}{rrrr}
\hline Sub Total & 0.535 & 2.362 & 1.265 \\
\hline Total & 1,000 & Rata2 & \multirow{2}{*}{2.714} \\
& & 2.747 & \\
\hline
\end{tabular}

Peluang yang memiliki nilai tertinggi adalah 0,360 yaitu "Akses transportasi dari dan menuju tempat wisata di Pesisir Selatan memadai”. Hal ini menunjukkan bahwa untuk menjangkau tempat wisata di Kabupaten Pesisir Selatan, responden tidak mengalami kendala dalam hal kendaraan transportasi mau pun dari akses jalan yang cukup memadai. Sedangkan ancaman terbesar yang memiliki skor tertinggi 0,295 adalah "Biro perjalanan wisata memiliki daftar akomodasi yang sesuai dengan panduan umum akomodasi pariwisata syariah". Hal ini menunjukkan bahwa biro perjalanan wisata di Kabupaten Pesisir Selatan belum memiliki daftar akomodasi yang sesuai dengan panduan umum akomodasi pariwisata syariah.

Matrik EFAS menunjukkan nilai faktor eksternal potensi wisata syariah di Kabupaten Pesisir Selatan yang sebesar 2,714 , berada di bawah nilai rata-ratanya yang sebesar 2,747 dari keseluruhan faktor eksternalnya. Hal ini menunjukkan bahwa potensi wisata syariah di Kabupaten Pesisir Selatan belum tergali seluruhnya dengan memanfaatkan peluang yang ada. Hasil nilai peluang sebesar 1,449 menunjukkan angka yang lebih besar dibandingkan dengan ancaman, yaitu sebesar 1,265. Hal ini menunjukkan bahwa peluang pengembangan wisata syariah di Kabupaten Pesisir Selatan lebih besar dari pada ancaman yang ada. Karena itu potensi wisata syariah di Kabupaten
Pesisir Selatan sangat pantas untuk dikembangkan lebih jauh lagi.

\section{Analisis SWOT}

Hasil perhitungan faktor internal dan eksternal tersebut dapat digambarkan dalam diagram kuadran SWOT.

\begin{tabular}{|c|c|c|}
\hline EFAS IFAS & STRENGHT (S) & $\begin{array}{c}\text { WEAKNESSES } \\
\text { (W) }\end{array}$ \\
\hline $\begin{array}{c}\text { OPPORTUNITIES } \\
\text { (O) }\end{array}$ & $\begin{array}{l}\text { STRATEGI S-O } \\
=2,659+1,449 \\
=4,108\end{array}$ & $\begin{array}{l}\text { STRATEGI W-O : } \\
=0,443+1,449 \\
=1,882\end{array}$ \\
\hline THREATS (T) & $\begin{array}{l}\text { STRATEGI S-T } \\
=2,659+1,265 \\
=3,924\end{array}$ & $\begin{array}{l}\text { STRATEGI W-T } \\
=0,443+1,265 \\
=1,708\end{array}$ \\
\hline
\end{tabular}

Gambar 1.

\section{Diagram Kuadran SWOT}

Gambar diatas menunjukkan bahwa strategi yang dapat digunakan adalah strategi kuadran I (strategi S-O), yaitu memanfaatkan seluruh kekuatan untuk merebut dan memanfaatkan peluang sebesar-besarnya. Rekomendasi strategi yang diberikan adalah strategi Agresif, artinya posisi wisata syariah di Kabupaten Pesisir Selatan dalam kondisi prima dan mantap sehingga sangat memungkinkan

untuk terus melakukan ekspansi, memperbesar pertumbuhan dan meraih kemajuan secara maksimal.

Analisis SWOT ini diterjemahkan ke dalam matriks SWOT yang menggambarkan secara jelas bagaimana kondisi yang dihadapi. 


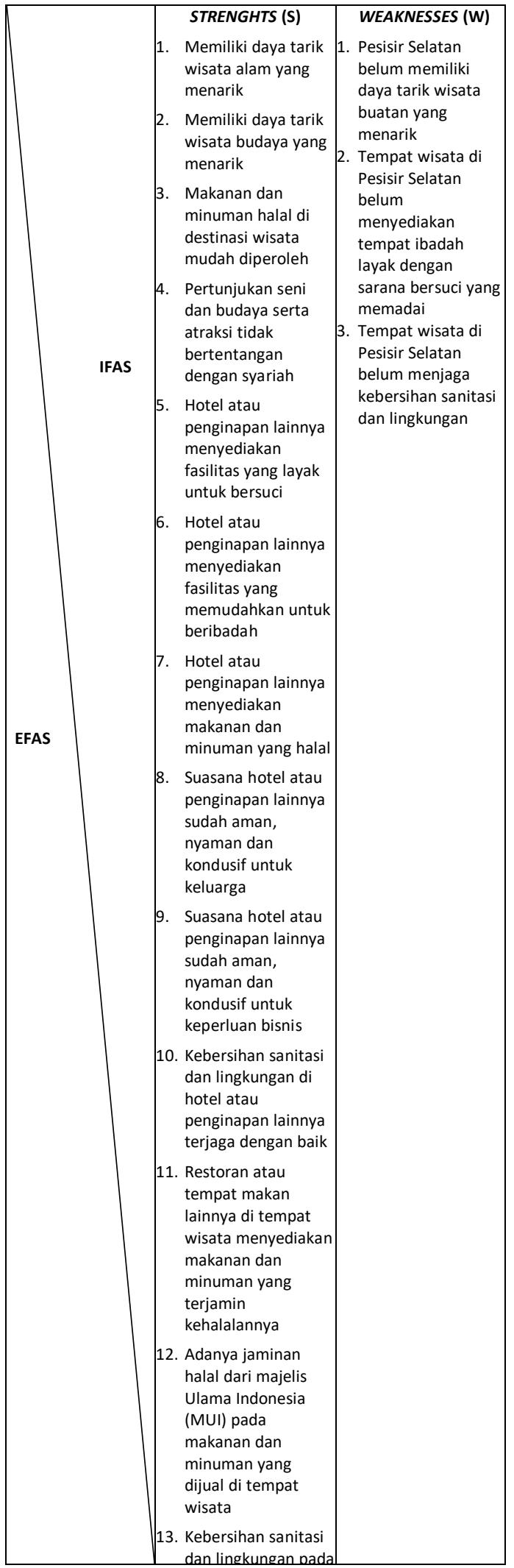

\begin{tabular}{|c|c|c|c|}
\hline $\begin{array}{l}\text { 1. Biro perjalanan } \\
\text { wisata } \\
\text { menyediakan } \\
\text { paket wisata } \\
\text { yang sesuai } \\
\text { dengan kriteria } \\
\text { umum } \\
\text { pariwisata } \\
\text { syariah } \\
\text { 2. Pramuwisata } \\
\text { memahami } \\
\text { dan mampu } \\
\text { melaksanakan } \\
\text { nilai-nilai } \\
\text { syariah dalam } \\
\text { bertugas } \\
\text { 3. Pramuwisata } \\
\text { memiliki } \\
\text { akhlak yang } \\
\text { baik, } \\
\text { komunikatif, } \\
\text { ramah, jujur } \\
\text { dan } \\
\text { bertanggungja }\end{array}$ & 1. & $\begin{array}{l}\text { STRATEGI S-O } \\
\text { Memanfaatkan } \\
\text { daya tarik wisata } \\
\text { alam dan budaya, } \\
\text { diisi dengan } \\
\text { pertunjukan seni } \\
\text { budaya dan atraksi, } \\
\text { ditunjang oleh biro } \\
\text { perjalanan wisata } \\
\text { yang menyediakan } \\
\text { paket wisata yang } \\
\text { sesuai dengan } \\
\text { kriteria umum } \\
\text { pariwisata syariah, } \\
\text { dan pramuwisata } \\
\text { yang memahami } \\
\text { dan mampu } \\
\text { melaksanakan nilai- } \\
\text { nilai syariah dalam } \\
\text { bertugas } \\
\text { Memanfaatkan } \\
\text { semaksimal } \\
\text { mungkin objek } \\
\text { wisata yang mudah } \\
\text { dijangkau dengan } \\
\text { akses transportasi } \\
\text { yang memadai } \\
\text { ditambah dengan } \\
\text { promosi } \\
\text { kemudahan } \\
\text { memperoleh } \\
\text { makanan dan } \\
\text { minuman halal } \\
\text { serta kebersihan } \\
\text { sanitasi dan } \\
\text { lingkungan yang } \\
\text { secara umum } \\
\text { terjaga dengan baik } \\
\text { harus untuk } \\
\text { menarik minat } \\
\text { wisatawan syariah } \\
\text { Mengedepankan } \\
\text { ketersedian hotel } \\
\text { atau penginapan } \\
\text { lainnya dengan } \\
\text { fasilitas yang layak } \\
\text { untuk bersuci dan } \\
\text { beribadah serta } \\
\text { kebersihan sanitasi } \\
\text { dan lingkungan } \\
\text { yang terjaga } \\
\text { dengan baik } \\
\text { ditunjang dengan } \\
\text { suasana vang }\end{array}$ & $\begin{array}{l}\text { STRATEGI W-O } \\
\text { 1. Menonjolkan } \\
\text { keberadaan objek } \\
\text { wisata yang mudah } \\
\text { dijangkau dengan } \\
\text { akses transportasi } \\
\text { yang memadai, biro } \\
\text { perjalanan wisata } \\
\text { yang menyediakan } \\
\text { paket wisata sesuai } \\
\text { syariah, dengan } \\
\text { pramuwisata yang } \\
\text { memahami dan } \\
\text { mampu } \\
\text { melaksanakan nilai- } \\
\text { nilai syariah dalam } \\
\text { bertugas, } \\
\text { berakhlak baik, } \\
\text { komunikatif, } \\
\text { ramah, jujur dan } \\
\text { bertanggung jawab } \\
\text { untuk menutupi } \\
\text { kelemahan Pesisir } \\
\text { Selatan yang belum } \\
\text { memiliki objek } \\
\text { wisata buatan yang } \\
\text { menarik } \\
\text { 2. Biro perjalanan } \\
\text { wisata dan } \\
\text { pramuwisata } \\
\text { mengutamakan } \\
\text { paket wisata ke } \\
\text { tempat-tempat } \\
\text { wisata yang sudah } \\
\text { menyediakan } \\
\text { tempat ibadah dan } \\
\text { sarana bersuci yang } \\
\text { layak serta sudah } \\
\text { terjaga kebersihan } \\
\text { sanitasi dan } \\
\text { lingkungannya } \\
\text { daya tarik wisata } \\
\text { buatan yang sudah } \\
\text { ada dengan } \\
\text { menonjolkan } \\
\text { kemudahan } \\
\text { jangkauan dan } \\
\text { akses transportasi } \\
\text { yang memadai }\end{array}$ \\
\hline
\end{tabular}




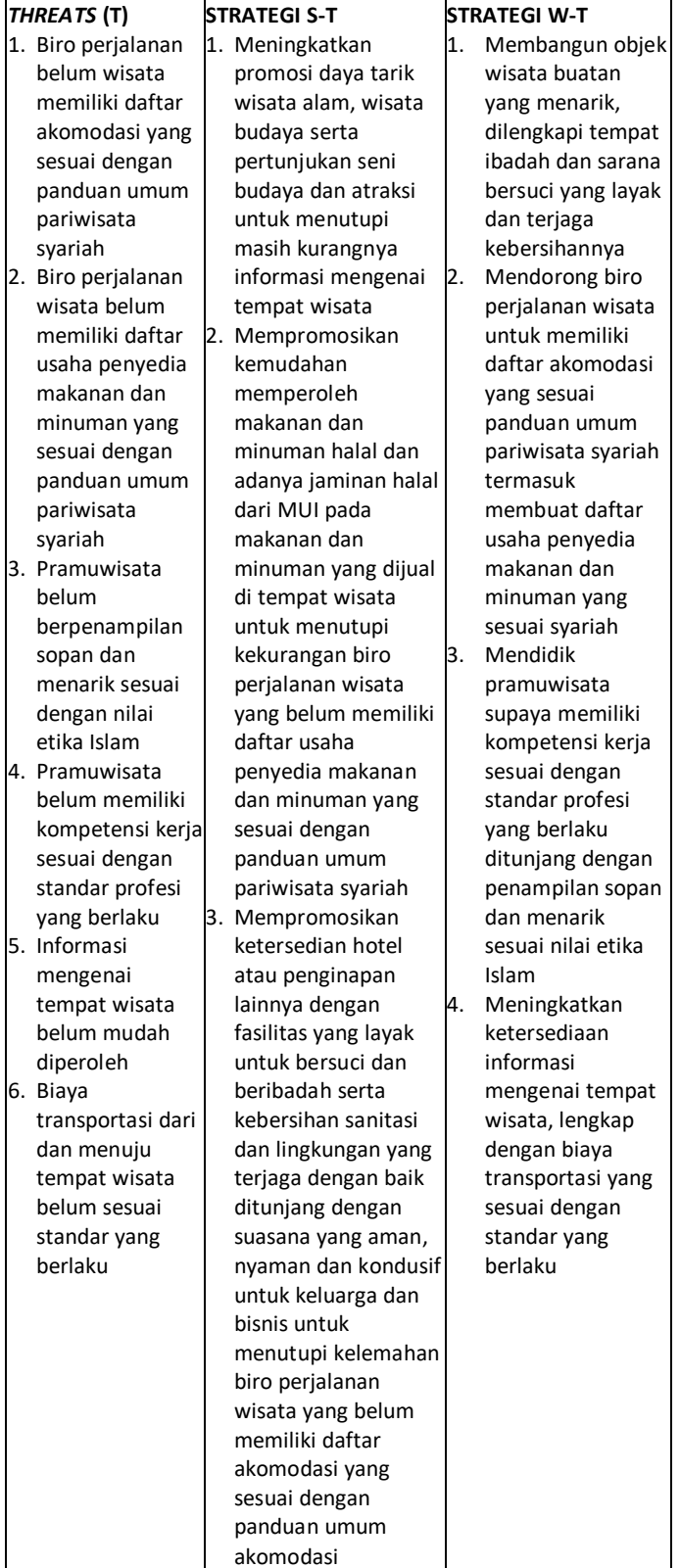

\section{Gambar 2.}

\section{Diagram Matrik SWOT Potensi Wisata Syariah}

Berdasarkan matriks SWOT ini maka strategi yang dapat digunakan untuk mengembangkan potensi wisata syariah di Kabupaten Pesisir Selatan adalah:

1. Memanfaatkan daya tarik wisata alam dan budaya, diisi dengan pertunjukan seni budaya dan atraksi, ditunjang oleh biro perjalanan wisata yang menyediakan paket wisata yang sesuai dengan kriteria umum pariwisata syariah, dan pramuwisata yang memahami dan mampu melaksanakan nilai-nilai syariah dalam bertugas

2. Memanfaatkan semaksimal mungkin objek wisata yang mudah dijangkau dengan akses transportasi yang memadai ditambah dengan promosi kemudahan memperoleh makanan dan minuman halal serta kebersihan sanitasi dan lingkungan yang secara umum terjaga dengan baik harus untuk menarik minat wisatawan syariah

3. Mengedepankan ketersedian hotel atau penginapan lainnya dengan fasilitas yang layak untuk bersuci dan beribadah serta kebersihan sanitasi dan lingkungan yang terjaga dengan baik ditunjang dengan suasana yang aman, nyaman dan kondusif untuk keluarga dan bisnis sebagai penarik minat wisatawan syariah

\section{Analisis Matrik Internal dan Eksternal (IE)}

Analisis internal menunjukkan bahwa jumlah nilai faktor internal adalah 3,102 . Pada analisa eksternal jumlah nilai faktor eksternal adalah 2,714. Selanjutnya digunakan matrik Internal Eksternal (IE) sebagai berikut:

\begin{tabular}{|c|c|c|c|}
\hline IFAS & $\begin{array}{c}\text { Kuat } \\
4,000- \\
3,000\end{array}$ & $\begin{array}{c}\text { Sedang } \\
2,999- \\
2,000\end{array}$ & $\begin{array}{c}\text { Lemah } \\
1,999- \\
1,000\end{array}$ \\
\hline $\begin{array}{c}\text { Tinggi } \\
4,000-3,000\end{array}$ & I & II & III \\
\hline $\begin{array}{c}\text { Sedang } \\
2,999-2,000\end{array}$ & $\begin{array}{c}\text { IV } \\
\text { Internal } \\
3,102 \\
\text { Eksternal } \\
2,714\end{array}$ & V & VI \\
\hline $\begin{array}{c}\text { Rendah } \\
1,999-1,000\end{array}$ & VI & VII & VIII \\
\hline
\end{tabular}

\section{Gambar 3. \\ Matrik Internal Eksternal (IE)}

Nilai matriks IFAS sebesar 3,102 menunjukkan bahwa wisata syariah di Pesisir Selatan memiliki faktor internal yang tergolong bagus dalam hal memanfaatkan kekuatan yang dimiliki 
untuk menutup kelemahan internal yang ada. Nilai matriks EFAS sebesar 2,714 menunjukkan bahwa wisata syariah di Pesisir Selatan memiliki kemampuan yang tergolong sedang atau cukup baik dalam hal memanfaatkan peluang yang dimiliki untuk mengatasi ancaman yang ada.

Posisi potensi wisata syariah di Kabupaten Pesisir Selatan berada dalam kuadran IV menunjukkan posisi tumbuh dan membangun (grow and built). Strategi yang paling tepat untuk digunakan adalah strategi intensif yang meliputi penetrasi pasar (market penetration), pengembangan pasar (market development), dan pengembangan produk (product development).

Hasil penelitian menunjukkan bahwa secara internal, potensi wisata syariah di Kabupaten Pesisir Selatan memiliki beberapa kekuatan berupa makanan dan minuman halal di destinasi wisata mudah diperoleh, hotel atau penginapan lainnya menyediakan makanan dan minuman yang halal, restoran atau tempat makan lainnya di tempat wisata menyediakan makanan dan minuman yang terjamin kehalalannya, hotel atau penginapan lainnya menyediakan fasilitas yang layak untuk bersuci, hotel atau penginapan lainnya menyediakan fasilitas yang memudahkan untuk beribadah, memiliki daya tarik wisata alam yang menarik, pertunjukan seni dan budaya serta atraksi tidak bertentangan dengan syariah, kebersihan sanitasi dan lingkungan pada penyedia makanan dan minuman di tempat wisata sudah terjaga dengan baik, kebersihan sanitasi dan lingkungan di hotel atau penginapan lainnya terjaga dengan baik, adanya jaminan halal dari Majelis Ulama Indonesia (MUI) pada makanan dan minuman yang dijual di tempat wisata, suasana hotel atau penginapan lainnya sudah aman, nyaman dan kondusif untuk keluarga, dan suasana hotel atau penginapan lainnya sudah aman, nyaman dan kondusif untuk keperluan bisnis.

Sedangkan kelemahan potensi wisata syariah di Kabupaten Pesisir Selatan adalah tempat wisata belum menyediakan tempat ibadah layak dengan sarana bersuci yang memadai, tempat wisata belum menjaga kebersihan sanitasi dan lingkungan, dan Pesisir Selatan belum memiliki daya tarik wisata buatan yang menarik.

Peluang yang ada adalah akses transportasi dari dan menuju tempat wisata sudah memadai, biro perjalanan wisata menyediakan paket wisata yang sesuai dengan kriteria umum pariwisata syariah, objek wisata mudah dijangkau, pramuwisata memahami dan mampu melaksanakan nilai-nilai syariah dalam bertugas, dan pramuwisata memiliki akhlak yang baik, komunikatif, ramah, jujur dan bertanggungjawab.

Sedangkan ancaman yang dihadapi adalah biro perjalanan wisata belum memiliki daftar akomodasi yang sesuai dengan panduan umum pariwisata syariah, biaya transportasi dari dan menuju tempat wisata belum sesuai standar yang berlaku, informasi mengenai tempat wisata belum mudah diperoleh, pramuwisata belum berpenampilan sopan dan menarik sesuai dengan nilai etika Islam, biroperjalanan wisata belum memiliki daftar usaha penyedia makanan dan minuman yang sesuai dengan panduan umum pariwisata syariah, dan pramuwisata belum memiliki kompetensi kerja sesuai dengan standar profesi yang berlaku.

Strategi yang dapat digunakan mengembangkan wisata syariah di Kabupaten Pesisir Selatan adalah memanfaatkan seluruh kekuatan untuk merebut dan memanfaatkan peluang sebesar-besarnya. Dipadu dengan strategi intensif yang meliputi penetrasi pasar (market penetration), pengembangan 
pasar (market development), dan pengembangan produk (product development).

Beberapa strategi penetrasi pasar yang bisa ditempuh demi mengembangkan potensi wisata syariah di Kabupaten Pesisir Selatan adalah melakukan penyesuaian harga, dimana dengan menurunkan berbagai harga seperti tarif sewa hotel dan lainnya, volume penjualan paket wisata dapat ditingkatkan. Kemudian meningkatkan promosi dengan menonjolkan keunggulan wisata syariah di Kabupaten Pesisir Selatan dari pada wisata di daerah lain. Strategi saluran distribusi dalam penetrasi pasar, misalnya menjual produk wisata syariah secara online sehingga bisa menarik minat wisatawan dari berbagai belahan dunia. Mengadakan berbagai acara, event baru di tempat wisata untuk komunitas tertentu juga berguna untuk menaikkan jumlah wisatawan.

Strategi pengembangan pasar yang dapat diterapkan adalah dengan memasuki pasar geografis baru. Misalnya mempromosikan wisata syariah di Kabupaten Pesisir Selatan ke Eropa untuk menarik minat kalangan non muslim mencoba wisata syariah. Strategi berikutnya bisa dengan menargetkan pelanggan baru di segmen baru. Misalnya dengan membuat destinasi wisata buatan dengan gaya dan tantangan yang saat ini sedang digandrungi oleh anak-anak muda tetapi semuanya tetap dikemas dalam konsep wisata syariah tentunya akan menyajikan suatu pengalaman yang unik.

Untuk pengembangan produk, beberapa strategi yang dapat ditempuh dalam mengembangkan potensi wisata syariah adalah meningkatkan produk yang sudah ada, seperti memperbaharui tempat wisata, memodifikasi dan menyesuaikan fasilitas wisata dengan keinginan pasar saat ini. Meningkatkan nilai produk juga bisa dilakukan, seperti memberikan fasilitas tambahan di tempat wisata bagi pengunjung yang menginap. Strategi lainnya adalah penawaran paket, seperti paket bulan madu, paket diskon, atau paket wisata keluarga.

\section{SIMPULAN}

Potensi wisata syariah di Kabupaten Pesisir Selatan memiliki lebih banyak kekuatan dan peluang dibanding kelemahan dan ancaman. Strategi yang dapat digunakan untuk mengembangkan wisata syariah di Kabupaten Pesisir Selatan adalah strategi agresif yaitu memanfaatkan seluruh kekuatan untuk merebut dan memanfaatkan peluang sebesar-besarnya. Untuk itu, diterapkan strategi penetrasi pasar, pengembangan pasar, dan pengembangan produk wisata.

Pengembangan wisata syariah di tengah pandemi Covid-19 harus mengikuti beberapa panduan yang wajib dipatuhi, seperti menerapkan protokol kesehatan di area wisata, sering membersihkan area servis dengan desinfektan untuk memenangkan kepercayaan wisatawan, mengutamakan take away service dan delivery order, memanfaatkan transaksi non tunai untuk memperkecil resiko, mengolah dan mengemas produk secara higienis untuk memenuhi tuntutan konsumen terhadap kesehatan dan beralih ke menu sehat yang dapat meningkatkan imunitas tubuh.

Para pemangku kepentingan industri pariwisata baik pemerintah maupun pihak swasta perlu membuat berbagai insentif untuk mendorong permintaan pariwisata dalam negeri di tengah melemahnya permintaan pariwisata internasional. Salah satu insentif yang bisa dibuat adalah penawaran diskon pesawat atau hotel dan akomodasi di tempat wisata.

DAFTAR PUSTAKA

Alim, Haidar Tsany, et. all. 2021. Analisis Potensi Pariwisata Syariah 
dengan Mengoptimalkan Industri Kreatif di Jawa Tengah dan Yogyakarta, dalam http://eprints.undip.ac.id/45828/1/Ar tikelpdf. diakses 27 Juli 2021

Andriani, D.,dkk, 2015, Pengembangan Wisata Syariah, Kemenpar, Jakarta.

Ansofino. 2012. Potensi Daya Tarik Obyek Pariwisata dalam Pembangunan Ekonomi Sumatera Barat. Economica, Jurnal Program Studi Pendidikan Ekonomi STKIP PGRI Sumatera Barat. Vol. 1 No. 1, Oktober

Bawazir, Thohir. 2013. Panduan Praktis Wisata Syariah. Jakarta: Pustaka AlKautsar.

Gunardi, Gugun. 2010. Identifikasi Potensi Kawasan Wisata Kali Pasir, Kota Tangerang. Jurnal PLANESA TM. Vo. 1, No. 1, Mei 2010

Hadiwijoyo, Suryo Sakti. 2012. Perencanaan Pariwisata Perdesaan Berbasis Masyarakat. Yogyakarta: Graha Ilmu

Haluan.wordpress.com/2007

Herfita, Devi , Tri Widyastuti, Irvandi Gustari. 2017. Analisis Strategi Bisnis Pada PT Gancia Citra. Jurnal EKSEKUTIF, Vol. 14, No. 2, Desember 2017

https://bali.tribunnews.com/2018/11/10/ kemenpar-targetkan-20-jutawisman-pada-2019-putridiharapkan-mampu-hadirkandestinasi-unik (Diakses tanggal 1 Agustus 2019)

https://bisnis.tempo.co/read/1429918/bps -pertumbuhan-ekonomi-indonesia2020-207-persen?page_num $=2$ (Diakses tanggal 28 Juli 2021)

https://bisniswisata.co.id/2018-

kunjungan-wisman-ke-sumbarmerosot/ (Diakses tanggal 2 Agustus 2019)

https://www.liputan6.com/bisnis/read/32 09609/sumatera-barat-dikunjungi- 78-juta-wisatawan-domestik-tahunini (Diakses tanggal 2 Agustus 2019) https://news.okezone.com/read/2018/

12/21/1/1994416/pariwisataindonesia-jadi-sumber-devisakemenpar-mantap-tatap-2019 https://sumatra.bisnis.com/read/2019020 4/534/885208/jumlah-wisman-kesumbar-2018-turun-441 (Diakses 2 Agustus 2021)

https://sumbartravel.com/wpcontent/uploads/dataupload/statistik \%20pariwisata\%20sumbar-2020.pdf Juwono, Onny. 2011. Analisis Manajemen Strategik Perusahaan Waralaba (Franchise) (Studi Kasus di Restoran Cepat Saji McDonald's) Periode Oktober - Desember 2011. http://fe.budiluhur.ac.id/wpcontent/uploads/2011/05/jurnalanalisis-manajemen-strategikmcdonalds_Onny_Yuwono.pdf. (Diakses tanggal 25 Juli 2020)

Kemenpar. Kemenparekraf Promosikan Indonesia Sebagai Destinasi Pariwisata Syariah Dunia. http://www.kemenpar.go.id (diakses 27 Juli 2021)

Kemenpar. Kemenparekraf Promosikan Indonesia Sebagai Destinasi Pariwisata Syariah Dunia. http://www.kemenpar.go.id (diakses 27 Juli 2021)

Masbiran, Vivi Ukhwatul K. 2020. Dampak Pandemi Covid-19 Terhadap Pariwisata Sumatera Barat Impact Of The Covid-19 Pandemic On West Sumatera Tourism. Jurnal Pembangunan Nagari. Volume 5 Nomor 2 Edisi Desember 2020 : 148 - 164

Moleong, Lexy J. 2004. Metodologi Penelitian Kualitatif. Bandung: PT. Remaja Rosdakarya

Noviantoro, Kurnia Maulidi dan Achmad Zurohman. 2020. Prospek Pariwisata Syariah (Halal Tourism): Sebuah Tantangan di Era Revolusi Industri 
4.0, EQUILIBRIUM: Jurnal Ekonomi Syariah. Volume 8, Nomor 2, 275-296, P-ISSN: 2355-0228, EISSN: 2502-8316, http://journal.iainkudus.ac.id/index. php/equilibrium

Rangkuti, Freddy. 2014. Analisis SWOT: Teknik Membedah Kasus Bisnis. Jakarta: PT Gramedia Pustaka Utama Rendayani, Mentari, dan Unggul Priyadi. (tanpa tahun). Analisis Potensi Dan Strategi Pengembangan Wisata Syariah Puncak Mas Sukadanaham Bandar Lampung, Prosiding National Conference on Applied Business ISBN: (tanpa nomor)

Sancoko, Aldo Hardi. 2015. Strategi Pengembangan Bisnis Usaha Makanan dan Minuman pada Depot Time to Eat Surabaya. AGORA, Vol. 3, No. 1, (2015).

Sedarmayanti. 2014. Manajemen Strategi. Bandung: PT Refika Aditama

Silitonga, Samuel Saut Marihot, dan Putu Anom. 2016. Kota Tua Barus sebagai Daerah Tujuan Wisata Sejarah di Kabupaten Tapanuli Tengah. Jurnal Destinasi Pariwisata. ISSN: 2338-8811. Vol. 4 No 2.

Soedarso, Muchammad Nurif, dan Windiani. 2014. Potensi dan Kendala Pengembangan Pariwisata Berbasis Kekayaan Alam dengan Pendekatan Marketing Places (Studi Kasus Pengembangan Pariwisata di Kabupaten Bojonegoro). jsh Jurnal Sosial Humaniora. Vol 7, No.2, November 2014

Sucipto, Hery dan Fitria Andayani. 2014. Wisata Syariah: Karakter, Potensi, Prospek dan Tantangannya. Jakarta: Grafindo Books Media dan Wisata Syariah Consulting.

Sugiyono. 2004. Metode Penelitian Bisnis. Bandung: Alfabeta
Suryadana, M. Liga dan Vanny Octavia. 2015. Pengantar Pemasaran Pariwisata. Bandung: Alfabeta. 